\title{
DECARBOXYLATIVE ALLYLATION OF KETONE ENOLATES WITH Rh, Ir, AND Mo
}

\author{
E.C. Dunn, J.A. Tunge \\ 2010 Malott Hall, 1251 Wescoe Hall Dr., Lawrence, KS USA \\ e-mail: tunge@ku.edu
}

A variety of catalysts were investigated for their ability to impart branched regioselectivity in decarboxylative allylation reactions. While catalysts based on Mo, Rh, and Ir were active catalysts, their regioselectivities were low and the reactions required an equivalent of base for efficient coupling. Alternatively, a ruthenium-based catalyst was identified that operates under neutral conditions and gives high branched selectivity in decarboxylative allylations.

In conjunction with our studies on the palladium-catalyzed decarboxylative allylation of ketone enolates [1-9], we sought to identify other transition metal complexes that were viable catalysts for the allylation reaction. Specifically, we wanted to target catalysts that selectively formed branched, terminal alkene products (i.e., 2a) from the $\beta$-keto ester starting materials such as $\mathbf{1 a}$ (Scheme 1). We viewed the development of such a reaction as an important complement to the palladium-catalyzed system, which favors the synthesis of linear alkenes. In addition, this type of regioselectivity would allow for the development of an enantioselective variant of the decarboxylative allylation reaction for substrates such as 1a that do not give rise to symmetrically substituted $\pi$-allyl intermediates upon oxidative addition of the substrate to the transition metal catalyst.

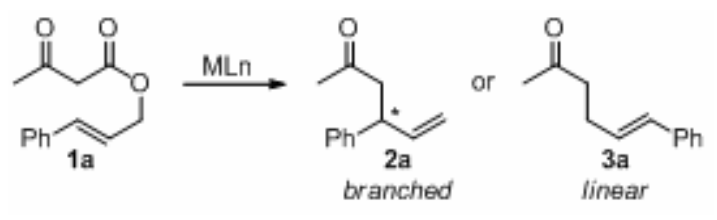

Scheme 1.

Iridium complexes are known to effectively catalyze the allylation of stabilized nucleophiles with very high selectivity for formation of branched alkene products [10-12]. In addition to this, results obtained by the Hartwig group indicated that iridium-phosphoramidite complexes are capable of inducing high levels of enantioselectivity in allylic etherification and amination reactions [13]. This made iridium complexes an attractive choice for catalyst development as they appeared to not only preferentially yield branched products in the related allylic alkylation of the stabilized nucleophiles, but also showed promise to do so with high levels of enantioselectivity.

$\beta$-Keto ester 1a was selected as a model substrate for the development of the proposed iridium-catalyzed decarboxylative allylation reaction. To begin, the 
compound 1a was subjected to $10 \mathrm{~mol} . \%[\operatorname{Ir}(\mathrm{COD}) \mathrm{Cl}]_{2}$ and $40 \mathrm{~mol} . \% \mathrm{P}(\mathrm{OPh})_{3}$ in THF. The reaction temperature was slowly increased to $65{ }^{\circ} \mathrm{C}$ in the course of 48 hours. The starting material remained unreacted until the temperature reached $65{ }^{\circ} \mathrm{C}$; at this temperature branched product $\mathbf{2 a}$ formed over the next 24 hours. Although the desired terminal alkene was the predominant product of the reaction by ${ }^{1} \mathrm{H}$ NMR spectroscopy data, attempts to repeat this reaction were largely unsuccessful. The reaction was also attempted in acetonitrile and methanol, however acetonitrile caused a large amount of iridium metal to deposit on the reaction flask and methanol only converted the keto ester 1a into the dimethyl ketal.

The effect of base was also explored. While the addition of potassium carbonate produced a very complex mixture of products, the addition of sodium hydride led to the unexpected isolation of the compound $\mathbf{4 a}$ in $24 \%$ yield (Scheme 2). Compound 4a presumably arises from diallylation of the acidic $\alpha$ position of keto ester 1a. The isolation of carboxylic acid product appears to indicate that decarboxylation of the $\operatorname{Ir}(\mathrm{III})$ allyl carboxylate intermediate is not facile under these conditions. Presumably the first allylation event occurs at the more substituted terminus of the Ir $\pi$-allyl, and is then followed by isomerization of the terminal double bond to form the trisubstituted alkene. This kind of isomerization is known to be catalyzed by $[\operatorname{Ir}(\mathrm{COD}) \mathrm{Cl}]_{2}$ under basic conditions [14]. Examination of the product further indicates that the second allylation occurs at the unsubstituted terminus of the $\pi$-allyl iridium intermediate, perhaps due to the increased steric hindrance present at the $\alpha$ position following the addition of the first allyl group. Changing the base from sodium hydride to cesium carbonate produced similar results, although the desired branched product $\mathbf{2 a}$, along with $\mathbf{2} \mathbf{a}^{\prime}$, derived from a double bond isomerization of the compound $\mathbf{2 a}$, is also formed in a 1:1:1 ratio (by ${ }^{1} \mathrm{H}$ NMR spectroscopy data). Replacing triphenylphosphite with tributylphosphite only led to formation of even more complex mixture of products.
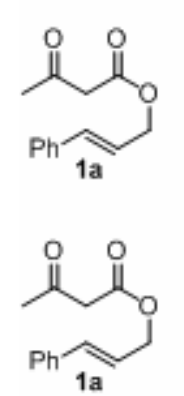
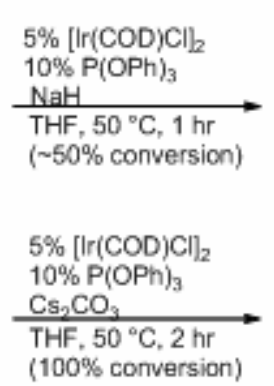

(100\% conversion)
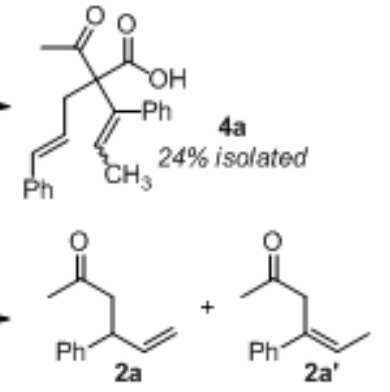

$1: 1: 1$

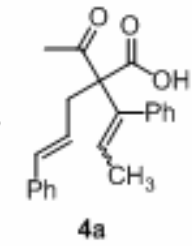

$4 a$

Scheme 2. Formation of carboxylic acid products

The addition of dimethylmalonate to the Ir-catalyzed reaction of the ester 1a with sodium hydride revealed that the intermolecular allylation of dimethylmalonate was faster than the intramolecular reaction (Scheme 3). This result demonstrates that formation of the Ir $\pi$-allyl is readily occurring upon addition of $[\operatorname{Ir}(\mathrm{COD}) \mathrm{Cl}]_{2}$ to a solution of the ester 1a. Unfortunately, decarboxylation and nucleophilic attack seem to be much more sluggish. These results led us to turn our attention to other transition metal complexes. 


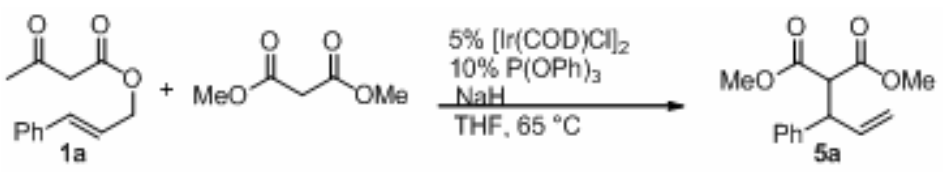

Scheme 3. Intermolecular allylation

\section{Efforts in the development of rhodium-catalyzed decarboxylative allylation reactions}

Rhodium complexes were viewed as an alternative to $[\operatorname{Ir}(\mathrm{COD}) \mathrm{Cl}]_{2}$ that would possibly undergo more facile decarboxylation. Rhodium has not been shown to catalyze the allylic alkylation of stabilized nucleophiles, $\mathrm{RhH}\left(\mathrm{PPh}_{3}\right)_{4}$ has been used successfully in the decarboxylative allylation reaction [15-19]. We initially focused on Wilkinson's catalyst, $\mathrm{RhCl}\left(\mathrm{PPh}_{3}\right)_{3}$, in the presence of different phosphite ligands.

Substrate 1a was again chosen as a model compound for the rhodium studies. Our initial experiment involved subjection of the ester 1a to $10 \mathrm{~mol} . \%$ $\mathrm{RhCl}\left(\mathrm{PPh}_{3}\right)_{3}$ and $30 \mathrm{~mol} . \% \mathrm{P}(\mathrm{OPh})_{3}$ in refluxing THF. Disappointingly, only starting material was present the reaction mixture after two days. We soon discovered that an equivalent of base was necessary for reaction to occur. The addition of sodium hydride led to the formation of the linear product 3a (Table 1, entry 1). While this result was encouraging, the compound 3a was not the isomer we desired. We found that changing the phosphite ligand from $\mathrm{P}(\mathrm{OPh})_{3}$ to $\mathrm{P}(\mathrm{OBu})_{3}$ led to the formation of the desired terminal alkene, however the linear isomer was formed along with it as a 1:1 mixture (entry 2). Changing the base from sodium hydride to cesium carbonate altered the selectivity to again favor production of the compound $\mathbf{3 a}$; only a trace amount of the compound 2a was observed by ${ }^{1} \mathrm{H}$ NMR spectroscopy.

Table 1. Survey of conditions

\begin{tabular}{|c|c|c|c|c|}
\hline Entry & Catalyst & Ligand & Base & $\mathrm{b}: 1(\text { conversion, } \%)^{\mathrm{a}}$ \\
\hline 1 & $\mathrm{RhCl}\left(\mathrm{PPh}_{3}\right)_{3}$ & $\mathrm{P}(\mathrm{OPh})_{3}$ & $\mathrm{NaH}$ & $0: 1(100 \%)$ \\
\hline 2 & $\mathrm{RhCl}\left(\mathrm{PPh}_{3}\right)_{3}$ & $\mathrm{P}(\mathrm{OBu})_{3}$ & $\mathrm{NaH}$ & $1: 1(100 \%)$ \\
\hline 3 & $\mathrm{RhCl}\left(\mathrm{PPh}_{3}\right)_{3}$ & $\mathrm{P}(\mathrm{OBu})_{3}$ & $\mathrm{Cs}_{2} \mathrm{CO}_{3}$ & $0: 1(100 \%)$ \\
\hline 4 & $\mathrm{Rh}(\mathrm{acac})\left(\mathrm{CH}_{2}=\mathrm{CH}_{2}\right)_{2}$ & - & $\mathrm{NaH}$ & $1: 2(75 \%)$ \\
\hline 5 & $\mathrm{Rh}(\mathrm{acac})\left(\mathrm{CH}_{2}=\mathrm{CH}_{2}\right)_{2}$ & $\mathrm{P}(\mathrm{OBu})_{3}$ & $\mathrm{Cs}_{2} \mathrm{CO}_{3}$ & $1: 2(100 \%)$ \\
\hline 6 & $\mathrm{Rh}(\mathrm{acac})\left(\mathrm{CH}_{2}=\mathrm{CH}_{2}\right)_{2}$ & $\mathrm{P}(\mathrm{OBu})_{3}$ & $\mathrm{NaH}$ & $1: 2(70 \%)$ \\
\hline 7 & $\mathrm{Rh}(\mathrm{acac})\left(\mathrm{CH}_{2}=\mathrm{CH}_{2}\right)_{2}$ & $\mathrm{P}(\mathrm{OPh})_{3}$ & $\mathrm{NaH}$ & $0: 1(40 \%)$ \\
\hline
\end{tabular}

${ }^{\mathrm{a}}$ conversion degree determined by ${ }^{1} \mathrm{H}$ NMR spectroscopy

We also explored other rhodium sources in the reaction. While $\mathrm{Rh}$ (acac) $(\mathrm{CO})_{2}$ failed to catalyze the decarboxylation of starting material, $\mathrm{Rh}(\mathrm{acac})\left(\mathrm{CH}_{2}=\mathrm{CH}_{2}\right)_{2}$ displayed catalytic activity, although the product selectivity remained poor. The reaction of the compound 1a with 
$\mathrm{Rh}(\mathrm{acac})\left(\mathrm{CH}_{2}=\mathrm{CH}_{2}\right)_{2}, \mathrm{P}(\mathrm{OBu})_{3}$, and either sodium hydride or cesium carbonate yielded of the branched and linear products in 1:2 ratio (entries 6 and 7). As was the case when Wilkinson's catalyst was employed as the Rh source, the addition of $\mathrm{P}(\mathrm{OPh})_{3}$ led to exclusive formation of the linear isomer (Entry 7). We also examined the effect of less polar solvent. Unfortunately, reactions conducted in refluxing toluene did not yield any product.

Dimethyl malonate was also introduced into the reaction of the ester 1a with $10 \mathrm{~mol} \%$ of $\mathrm{RhCl}\left(\mathrm{PPh}_{3}\right)_{3}, 30 \mathrm{~mol} \%$ of $\mathrm{P}(\mathrm{OPh})_{3}$ and $\mathrm{NaH}$ (Scheme 4). Unlike the reaction with iridium, only intramolecular allylation occurred. No products arising from the allylation of dimethyl malonate were observed.

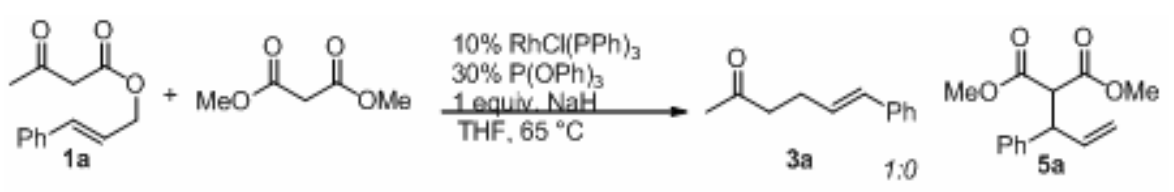

Scheme 4. Intramolecular allylation.

While the formation of 1:1 mixture of regioisomers (Table 1, entry 2) from linear starting material indicates that the mechanism of decarboxylative allylation does not proceed by a simple double $S_{N} 2$ displacement as proposed by Evans for the allylation of stabilized nucleophiles, the lack of any appreciable selectivity for the formation of branched, terminal alkene product in the rhodium-catalyzed decarboxylative allylation reaction led us to explore other catalysts.

\section{Molybdenum-catalyzed decarboxylative allylation reactions}

The screening of molybdenum complexes for catalytic activity also began with $\beta$-keto ester 1a [16-19]. In one of the initial experiments the ester 1a was subjected to $10 \mathrm{~mol} \%$ of $\left(\mathrm{C}_{7} \mathrm{H}_{7}\right) \mathrm{Mo}(\mathrm{CO})_{3}$ and $10 \mathrm{~mol} \%$ of tert-butyl bipyridine ('Bu-bpy) in refluxing THF (Scheme 5). After 31 hours ${ }^{1} \mathrm{H}$ NMR spectroscopy indicated that the reaction had proceeded to only $30 \%$ conversion although, gratifyingly, the branched isomer 2a was the major product. In an effort to increase the rate of reaction, sodium hydride was added. This had an advantageous effect on the reaction; after additional 24 hours no starting material was detected by ${ }^{1} \mathrm{H}$ NMR spectroscopy. Instead it appeared that almost quantitative conversion to the desired terminal alkene had occurred (Scheme 5). Other bases such as cesium carbonate and BSA were uneffective at producing similar conversions.
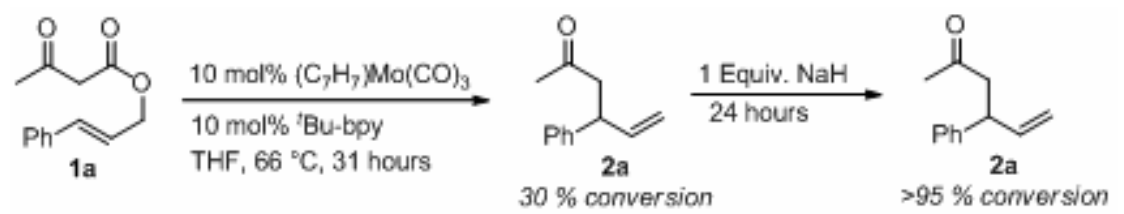

Scheme 5. Effect of adding base to the reaction mixture.

The selectivity of the reaction was slightly altered upon changing the solvent from THF to toluene and increasing the temperature to $110{ }^{\circ} \mathrm{C}$. When the ester 1 a was subjected to $10 \mathrm{~mol} . \%$ of $\left(\mathrm{C}_{7} \mathrm{H}_{7}\right) \mathrm{Mo}(\mathrm{CO})_{3}, 10 \mathrm{~mol} . \%$ of tert-Bu-bpy and 
one equivalent of $\mathrm{NaH}$ in refluxing toluene, the branched regioisomer was still the major product, although the linear isomer was also formed $(b: 1=61: 39)$. Repeating the experiment yielded a slightly improved 69:31 ratio of products.

We also explored the catalytic activity of $\mathrm{Mo}\left(\mathrm{CH}_{3} \mathrm{CN}\right)_{3}(\mathrm{CO})_{3}$. The reaction of the ester $1 \mathrm{a}$ with $10 \mathrm{~mol} \% \%$ of $\mathrm{Mo}\left(\mathrm{CH}_{3} \mathrm{CN}\right)_{3}(\mathrm{CO})_{3}, 10 \mathrm{~mol} . \%$ of bipyridine, and sodium hydride afforded a slightly reduced ratio (56:44) of allylation products favoring the formation of the branched isomer. Running the reaction without base yielded only a trace amount of the product. The reaction was also conducted in the presence of dimethyl malonate; it was found that intramolecular allylation occurred only (Scheme 6).

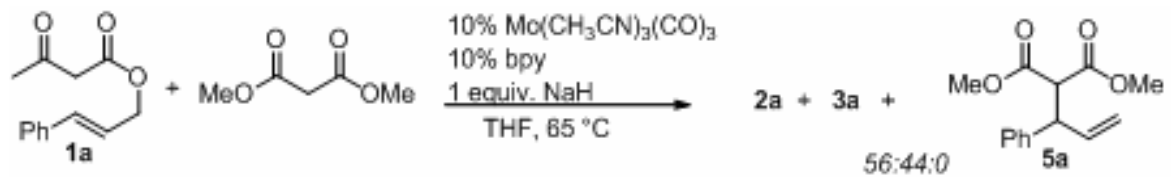

Scheme 6. Intramolecular allylation.

Substrate 1b was synthesized in order to probe the reactivity of the ketone substrates containing $\alpha$ substituents. As illustrated in the Scheme 7, compound 1b was successfully allylated when sodium hydride was added to the reaction mixture. The regioselectivity of the reaction was hoted to be reverse after altering the enolate to cyclohexanone. Specifically, the linear product $\mathbf{3 b}$ was favoured over the branched product in a 1:2 ratio. The reversal of regioselectivity is in line with the observation of the Trost group that increasing the size of the nucleophile can lead to an increase in the amount of nucleophilic attack at the unsubstituted terminus of the Mo $\pi$-allyl complex [20, 21].
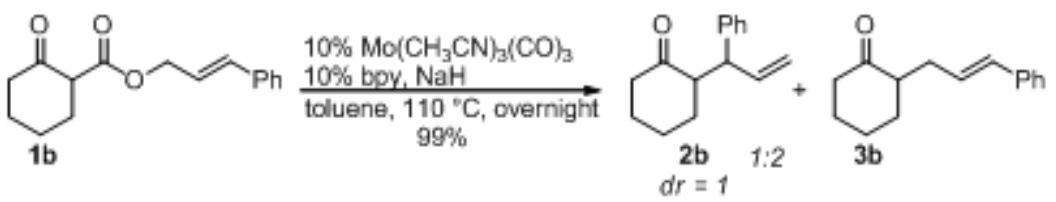

Scheme 7. Regioselectivity of allylation.

The scope of the reaction was further explored by synthesizing the crotyl alcohol derived $\beta$-keto ester 1c (Scheme 8). Substrate 1c participated in the decarboxylative allylation reaction to afford a mixture of products as stafed by ${ }^{1} \mathrm{H}$ NMR. One half of the mixture consisted of the terminal alkene $\mathbf{3 c}$, and the remaining material primarily consisted of the linear product, along with what was tentatively identified as diallylated product.

As was the case for the compound $\mathbf{1 b}$, the bulkier cylclohexanone derivative of $\mathbf{1 d}$ reacted to preferentially form the linear product in a 1:4 ratio (Scheme 8). Unfortunately, the cyclohexenol-derived compound 1e did not participate in the reaction. The selectivity of these reactions was not considered to be high enough to pursue molybdenum-catalyzed reactions any further, especially given our concurrent development of ruthenium-catalyzed decarboxylative allylation reactions which proceeded under much milder conditions. 


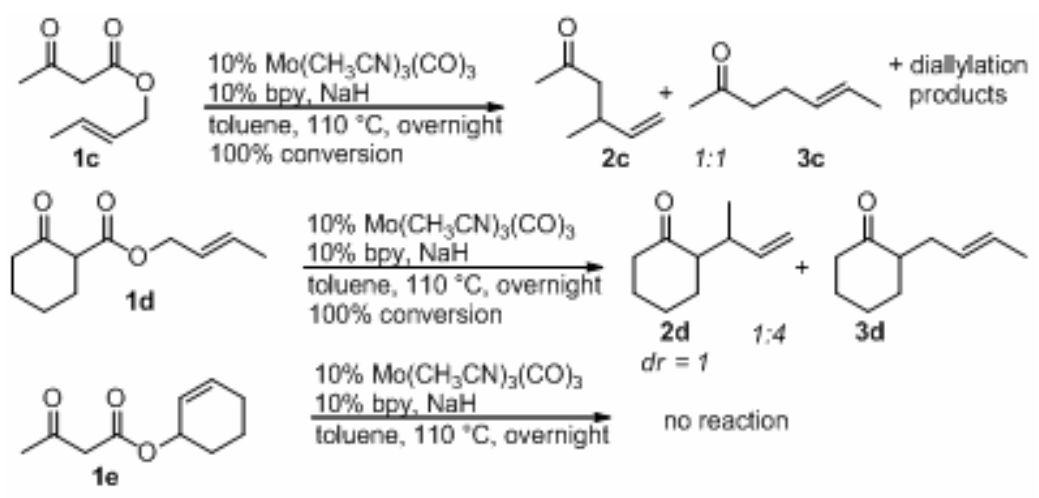

Scheme 8. Regioselectivity of allylation.

\section{Ruthenium-catalyzed decarboxylative allylation reactions}

We were interested in pursing ruthenium catalysts for the decarboxylative allylation reaction for the same reasons that we were interested in iridium, rhodium, and molybdenum catalysts; ruthenium-catalyzed allylic alkylations had been shown to proceed with high levels of regioselectivity favouring formation of branched products [22-30]. In addition to this, the almost perfect retention of configuration demonstrated by Trost in the allylation of stabilized nucleophiles with chiral, non-racemic allylic carbonates [30] hinted at the possibility of developing a stereospecific decarboxylative allylation reaction. Unlike iridium, rhodium, and molybdenum, ruthenium proved to be capable of catalyzing very regioselective decarboxylative allylation reactions under extremely mild reaction conditions.

Many of the reported $\mathrm{Ru}$ complexes that catalyze highly regioselective allylation reactions contain a $\mathrm{Cp}^{*}$ ligand, therefore many of the ruthenium complexes screened for catalytic activity in the decarboxylative allylation reaction contained this ligand. One of these complexes, $\left[\mathrm{Cp}^{*} \mathrm{RuCl}\right]_{4}$, along with bipyridine (bpy) ligand, was screened for activity with a variety of $\beta$-keto ester substrates.

Table 2. Substrate scope

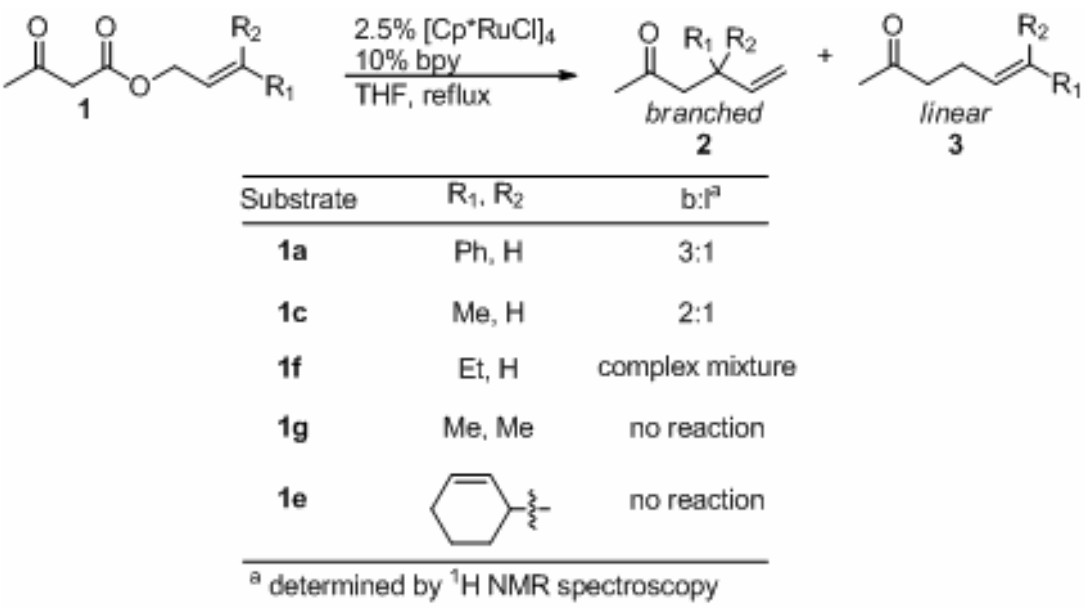

It is apparent when examining the results in Table 2.3 that aryl-substituted $\beta$ keto esters undergo reaction much more readily than those containing alkyl 
substituents. Substrate 1a reacted with the highest regioselectivity, 3:1, in favour of the branched isomer. While the compound 1c reacted with moderate selectivity (2:1), the closely related ethyl analog, $\mathbf{1 f}$, afforded a complex mixture of products under the conditions of catalysis. Substrates $\mathbf{1 g}$ and $1 \mathrm{e}$ failed to yield any decarboxylation products. Due to its more favorable reactivity, the ester 1a was selected for further optimization studies [31].

A series of ruthenium complexes were screened for activity in the presence of different ligands. Table 3 shows the results obtained when $10 \mathrm{~mol} \%$ of ruthenium and $10 \mathrm{~mol} \%$ of ligand were employed as the catalyst. The ruthenium tetramer, $[\mathrm{Cp} * \mathrm{RuCl}]_{4}$, was the most active and regioselective catalyst, although the addition of bipyridine was critical for achieving the best results. For instance, catalysis with $2.5 \mathrm{~mol} . \%$ of $[\mathrm{Cp} * \mathrm{RuCl}]_{4}$ and no additional ligand in methylene chloride only proceeded to $9 \%$ conversion degree in $1.5 \mathrm{~h}$ and ultimately yielded a 6.2:1 ratio of regioisomers (branched:linear), whereas upon the addition of bipyridine the reaction was complete in 1.5 hours and linear product was not visible in the ${ }^{1} \mathrm{H}$ NMR spectrum of the crude product. The addition of two equivalents of pyridine failed to generate a catalyst that was comparable to the combination of $[\mathrm{Cp} * \mathrm{RuCl}]_{4}$ and bipyridine. This is most likely due to the reported formation of $\mathrm{Ru}$ dimer, rather than the desired monomer, upon the addition of pyridine to $[\mathrm{Cp} * \mathrm{RuCl}]_{4}$ [32]. This complex produced the branched product in 2.5:1 ratio along with the linear product. The addition of the bidentate ligand TMEDA (tetramethylenediamine) improved the selectivity somewhat (9.1:1), but bipyridine is still clearly the optimal ligand for the reaction.

Table 3. Catalyst optimization

\begin{tabular}{|c|c|c|c|c|c|c|}
\hline$[\mathrm{Ru}]$ & Ligand & Time, $\mathrm{h}$ & Solvent & $\begin{array}{l}\text { Tempera- } \\
\text { ture, }{ }^{\circ} \mathrm{C}\end{array}$ & $\begin{array}{c}\text { Conversion } \\
\text { degree, } \%\end{array}$ & $\mathrm{~b}: 1$ \\
\hline$[\mathrm{Cp} * \mathrm{RuCl}]_{4}$ & - & 1.5 & $\mathrm{CH}_{2} \mathrm{Cl}_{2}$ & 25 & 9 & $6.2: 1$ \\
\hline$[\mathrm{Cp} * \mathrm{RuCl}]_{4}$ & $\begin{array}{l}2 \text { equiv. } \\
\text { pyridine }\end{array}$ & 1.5 & $\mathrm{CH}_{2} \mathrm{Cl}_{2}$ & 25 & 19 & $2.5: 1$ \\
\hline$[\mathrm{Cp} * \mathrm{RuCl}]_{4}$ & bpy & 1.5 & $\mathrm{CH}_{2} \mathrm{Cl}_{2}$ & 25 & 100 & $>19: 1$ \\
\hline$[\mathrm{Cp} * \mathrm{RuCl}]_{4}$ & TMEDA & 4 & $\mathrm{CH}_{2} \mathrm{Cl}_{2}$ & 25 & 100 & $9.1: 1$ \\
\hline$[\mathrm{Cp} * \mathrm{RuCl}]_{4}$ & bpy & 4 & THF & 25 & 100 & $10.7: 1$ \\
\hline$[\mathrm{Cp} * \mathrm{RuCl}]_{4}$ & - & 1.5 & $\mathrm{CH}_{3} \mathrm{CN}$ & 50 & 66 & $3: 1$ \\
\hline$[\mathrm{Cp} * \mathrm{RuOMe}]_{2}$ & bpy & 0.25 & $\mathrm{CH}_{2} \mathrm{Cl}_{2}$ & 25 & 25 & $10: 1$ \\
\hline (methyl) $)_{2} \mathrm{Ru}(\mathrm{COD})$ & bpy & 16 & $\mathrm{CH}_{2} \mathrm{Cl}_{2}$ & 65 & 100 & $2: 1$ \\
\hline (methyl) ${ }_{2} \mathrm{Ru}(\mathrm{COD})$ & - & 16 & $\mathrm{CH}_{2} \mathrm{Cl}_{2}$ & 40 & no reaction & \\
\hline (methyl) $)_{2} \mathrm{Ru}(\mathrm{COD})$ & bpy & 16 & $\mathrm{CH}_{2} \mathrm{Cl}_{2}$ & 40 & no reaction & \\
\hline $\mathrm{CpRu}\left(\mathrm{NCCH}_{3}\right)_{3} \mathrm{PF}_{6}$ & bpy & 16 & $\mathrm{CH}_{2} \mathrm{Cl}_{2}$ & 25 & 49 & $10: 1$ \\
\hline$\left[\mathrm{RuCl}_{2} \text { (cymene) }\right]_{2}$ & bpy & 16 & $\mathrm{CH}_{2} \mathrm{Cl}_{2}$ & 25 & no reaction & \\
\hline$\left[\mathrm{RuCl}_{2}(\mathrm{BINAP})\right]_{\mathrm{x}}$ & bpy & 16 & $\mathrm{CH}_{2} \mathrm{Cl}_{2}$ & 25 & no reaction & \\
\hline $\mathrm{RuCl}_{2}(\mathrm{COD})$ & bpy & 16 & $\mathrm{CH}_{2} \mathrm{Cl}_{2}$ & 25 & no reaction & \\
\hline$-\mathrm{NH}\left({ }^{i} \mathrm{Pr}\right)$ & - & 16 & THF & 65 & no reaction & \\
\hline
\end{tabular}


Solvent and reaction temperature also influenced the outcome of the reaction. For example, when THF was used as the solvent in the presence of $[\mathrm{Cp} * \mathrm{RuCl}]_{4}$ and bipyridine, a 10.7:1 mixture of regioisomers was obtained after four hours, compared to the $>19: 1$ mixture obtained after 1.5 hours when the solvent was methylene chloride. Even more significantly, when the substrate was allowed to react in refluxing THF, the regioselectivity plummeted to 3:1.

Having identified the optimal catalytic system for the Ru-catalyzed decarboxylative allylation reaction as $2.5 \mathrm{~mol} \%$ of $\left[\mathrm{Cp}^{*} \mathrm{RuCl}\right]_{4}$ and $10 \mathrm{~mol} . \%$ of bipyridine in methylene chloride at room temperature, we sought to expand the substrate scope. A brief reexamination of alkyl substituted $\beta$-keto esters such as compounds 1e and 1f indicated that these substrates did not react under the optimized conditions. Thus, we chose to focus on the rearrangement of arylsubstituted $\beta$-keto esters.

As Table 4 shows, a variety of cinnamyl $\beta$-keto esters possessing electronwithdrawing and electron-donating groups reacted cleanly to give very high yields of branched products. While substrates possessing electron-donating groups such as the compound $\mathbf{1 j}$ underwent complete conversion to product very rapidly, substrates bearing electron-withdrawing groups reacted much more slowly. The presence of an ortho substituent also slowed the reaction considerably. So, with the compound $\mathbf{1 i}$ if took five days to reach complete conversion. We attribute the decreased reactivity of the compound 1i to the increased steric hindrance present in close proximity to the alkene. This may inhibit the precoordination of $\mathrm{Ru}$, which has been proposed to initiate ionization of the leaving group in Ru-catalyzed allylic alkylation reactions [22-29]. Substrate 1o, possessing an acidic proton, reacted to yield a complex mixture of products including the compound $\mathbf{2 0}$, which was isolated in only an $18 \%$ yield.

Table 4. Substrate scope

\begin{tabular}{|c|c|c|c|c|c|c|c|c|c|}
\hline $\begin{array}{l}\text { Sub- } \\
\text { strate }\end{array}$ & $\mathrm{R}_{1}$ & $\mathrm{R}_{2}$ & Time & $\begin{array}{c}\text { Yield, } \\
\%\end{array}$ & $\begin{array}{c}\text { Sub- } \\
\text { strate }\end{array}$ & $\mathrm{R}_{1}$ & $\mathrm{R}_{2}$ & Time & $\begin{array}{c}\text { Yield, } \\
\%\end{array}$ \\
\hline $1 \mathrm{a}$ & $\mathrm{Ph}$ & $\mathrm{H}$ & $1.5 \mathrm{~h}$ & 94 & $1 \mathrm{~m}$ & $p-\mathrm{C}_{6} \mathrm{H}_{4} \mathrm{CF}_{3}$ & $\mathrm{H}$ & $40 \mathrm{~h}$ & 90 \\
\hline $1 \mathrm{~h}$ & $p$-tolyl & $\mathrm{H}$ & $2 \mathrm{~h}$ & 96 & $1 n$ & $\mathrm{Ph}$ & $\mathrm{Ph}$ & $1 \mathrm{~h}$ & 67 \\
\hline $1 \mathbf{i}$ & $o$-tolyl & $\mathrm{H}$ & $5 \mathrm{~d}$ & 81 & 10 & $p-\mathrm{C}_{6} \mathrm{H}_{4} \mathrm{OH}$ & $\mathrm{H}$ & $1 \mathrm{~h}$ & 18 \\
\hline $1 j$ & $p-\mathrm{C}_{6} \mathrm{H}_{4} \mathrm{OMe}$ & $\mathrm{H}$ & $15 \mathrm{~min}$ & 91 & $1 p$ & & $\mathrm{H}$ & $30 \mathrm{~min}$ & 61 \\
\hline $1 k$ & $o-\mathrm{C}_{6} \mathrm{H}_{4} \mathrm{OMe}$ & $\mathrm{H}$ & $15 \mathrm{~min}$ & 93 & & & & & \\
\hline 11 & $p-\mathrm{C}_{6} \mathrm{H}_{4} \mathrm{Cl}$ & $\mathrm{H}$ & $4 \mathrm{~h}$ & 96 & & & & & \\
\hline & & & 1a' & $\begin{array}{l}2.5 \% \text { [C } \\
10 \% \text { bp }\end{array}$ & ${ }^{*} \mathrm{RuCl}_{4}$ & $93 \%$ isals & & & \\
\hline
\end{tabular}


Substrates that decarboxylate to yield enolates other than that derived from acetone were also subjected to catalysis with $[\mathrm{Cp} * \mathrm{RuCl}]_{4}$ and bipyridine. Cyclohexanone derived the compound $\mathbf{1 b}$ reacted slowly at room temperature, but provided a very good yield of the compound $\mathbf{2 b}$ (Scheme 9). Unfortunately the diastereoselectivity was only 1.9. The rearrangement of $\alpha$-chloro ester $\mathbf{1 q}$ was quite facile and occurred with a slightly improved dr of 3 .
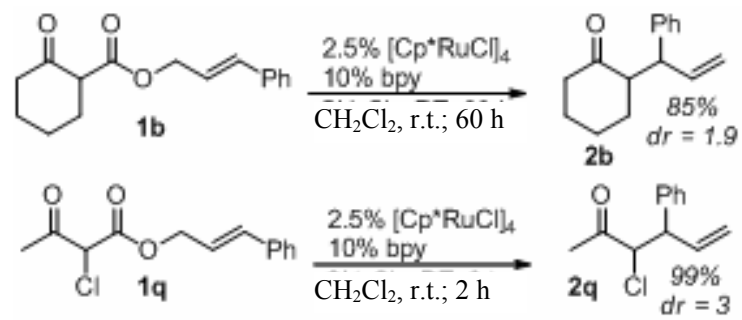

Scheme 9. Diastereoselectivity of allylation.

The presence of two $\alpha$ substituents slowed the reaction considerably (Scheme 10). Substrate 1r failed to react under standard conditions, however an allyl acetoacetate derivative 1s underwent decarboxylative coupling at high temperature to give the product $\mathbf{2 s}$.

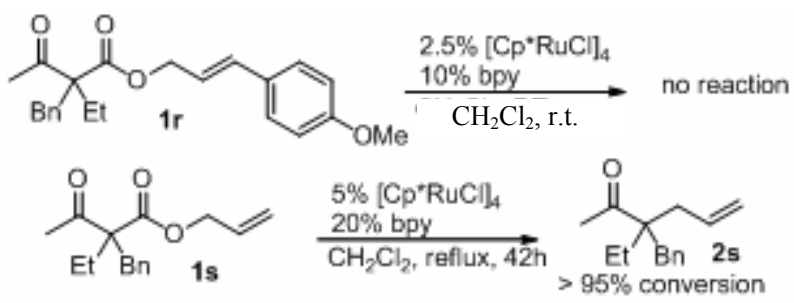

Scheme 10. Formation of quaternary centers.

In conclusion, a variety of transition metals were investigated for their ability impart branched regioselectivity in catalytic decarboxylative allylation reactions. While Ir, Mo, and $\mathrm{Rh}$ proved to be active catalysts in the presence of base, $\mathrm{Ru}$ was the most active. Furthermore $\left[\mathrm{Cp}^{*} \mathrm{RuCl}\right]_{4} /$ bpy was an efficient catalyst even in the absence of base. Moreover, it was the most regioselective catalyst, providing the formation exclusively of the branched products in high yield.

\section{R E F E R E N C E S}

1. Shimizu, I.; Yamada, T.; Tsuji, J. (1980). Tetrahedron Lett., 21, 3199.

2. Tsuda, T.; Chujo, Y.; Nishi, S.; Tawara, K.; Saegusa, T. (1980). J. Am. Chem. Soc., 102, 6381.

3. Behenna, D. C.; Stoltz, B. M. (20040. J. Am. Chem. Soc., 126, 15044.

4. Mohr, J. T.; Behenna, D. C.; Harned, A. M.; Stoltz, B. M. (2005). Angew. Chem., Int. Ed., 44, 6924.

5. Trost, B. M.; Xu, J. (2005). J. Am. Chem. Soc., 127, 2846.

6. Trost, B. M.; Xu, J.; Schmidt, T. (2009). J. Am. Chem. Soc., 131, 18343.

7. Weaver, J. D.; Recio, A.; Grenning, A. J.; Tunge, J. A. (2011). Chem. Rev., 111, 1846-1913.

8. Burger, E. C.; Tunge, J. A. (2004). Org. Lett., 6, 2603.

9. Chattopadhyay, K.; Jana, R.; Day, V. W.; Douglas, J. T.; Tunge, J. A. (2010). Org. Lett. 
10. Takeuchi, R.; Kashio, M. (1997). Angew. Chem. Int. Ed., 36, 263-265.

11. Bartels, B.; Garcia-Yebra, C.; Rominger, F.; Helmchen, G. (2002). Eur. J. Inorg. Chem., 2569-2586.

12. Singh, O. V.; Han, H. (2007). J. Am. Chem. Soc., 129, 774-775.

13. Graening, T.; Hartwig, J. F. (2005). J. Am. Chem. Soc., 127, 17192-17193.

14. Higashino, T.; Sakaguchi, S.; Ishii, Y. (2000). Org. Lett., 2, 4193-4195.

15. Tsuji, J.; Minami, I.; Shimizu, I. (1984). Tetrahedron Lett., 25, 5157-5160.

16. Tsuji, J.; Minami, I.; Shimizu, I. (1984). Chem. Lett., 1721-1724.

17. Minami, I.; Shimizu, I.; Tsuji, J. (1985). J. Organomet. Chem., 296, 269-280.

18. Evans, P. A.; Nelson, J. (1998). Tetrahedron Lett., 39, 1725-1728.

19. Evans, P. A.; Nelson, J. (1998). J. Am. Chem. Soc., 120, 5581-5582.

20. Trost, B. M.; Lautens, M. (1982). J. Am. Chem. Soc., 104, 5543-5545.

21. Trost, B. M.; Lautens, M. (1983). J. Am. Chem. Soc., 105, 3343-3344.

22. Zhang, S.-W.; Mitsudo, T.-a.; Kondo, T.; Watanabe, Y. (1993). J. Organomet. Chem., 450, 197-207.

23. Kondo, H.; Ono, H.; Satake, N.; Mitsudo, T.; Watanabe, Y. (1995). Organometallics, 14, $1945-1953$.

24. Morisaki, Y.; Kondo, T.; Mitsudo, T. (1999). Organometallics, 18, 4742-4746.

25. Kondo, H.; Kageyama, A.; Yamaguchi, Y.; Haga, M.-A.; Kirchner, K.; Nagashima, H. (2001). Bull. Chem. Soc. Japan, 74, 1927-1937.

26. Matsushima, Y.; Onitsuka, K.; Kondo, T.; Mitsudo, T.; Takahashi, S. (2001). J. Am. Chem. Soc., 123, 10405-10406.

27. Mbaye, D.; Demerseman, B.; Renaud, J.-L.; Toupet, L.; Bruneau, C. (2003). Angew. Chem. Int. Ed., 42, 5066-5068.

28. Hermatschweiler, R.; Fernandez, I.; Pregosin, P. S.; Watson, E. J.; Albinati, A.; Rizzato, S.; Veiros, L. F.; Calhorda, M. J. (2005). Organometallics, 24, 1809-1812.

29. Constant, S.; Tortoioli, S.; Mueller, J.; Linder, D.; Buron, F.; Lacour, J. (2007). Angew. Chem., Int. Ed., 46, 8979.

30. Trost, B. M.; Fraisse, P. L.; Ball, Z. T. (2002). Angew. Chem. Int. Ed., 41, 1059-1061.

31. Burger, E. C.; Tunge, J. A. (2004). Org. Lett., 6, 2603-2605.

32. Chaudret, B.; Jalon, F.; Perez-Manrique, M.; Lahoz, F.; Plou, F. J.; Sanchez-Delgado, R. (1990). New J. Chem., 14, 331-338. 